\title{
Two New Megastigmanes from the Leaves of Cucumis sativus
}

\author{
Hisahiro KaI, Masaki BaBA, and Toru OKUYAmA* \\ Department of Natural Medicine and Phytochemistry, Meiji Pharmaceutical University; 2-522-1 Noshio, Kiyose, Tokyo \\ 204-8588, Japan. Received August 24, 2006; accepted October 14, 2006; published online October 17, 2006
}

\begin{abstract}
Two new megastigmane, cucumegastigmanes I (1) and II (2), together with a known megastigmane, (+)-dehydrovomifoliol (3), and five other known compounds were isolated from the leaves of Cucumis sativus. The structures of the new compounds were elucidated from spectroscopic analysis and their absolute stereochemistries were determined in detail using the chemical conversion and a modified Mosher's method.
\end{abstract}

Key words Cucumis sativus; cucumegastigmane I; cucumegastigmane II; megastigmane; modified Mosher's method

Cucumis sativus L., which belongs to the Cucurbitaceae family, is cultivated worldwide as a vegetable crop. The fruit of $C$. sativus (cucumber) is used not only as food, but also in folk medicines and folk cosmetics. The leaves, stems and roots of $C$. sativus are reportedly used in Chinese folk medicine as antidiarrheal, detoxicant and antigonorrheal agents. ${ }^{1)}$ However, these are not major uses, so after harvest of the cucumber fruits, almost all the remaining plant material is waste. There have been few chemical studies regarding the constituents of this material. The only reports are by Enslin et al., who isolated the triterpenoid cucurbitacin $\mathrm{C},{ }^{2)}$ and $\mathrm{Mc}-$ Nally et al., who isolated $C$-glycosyl flavonoid. ${ }^{3)}$ Thus, in the present study, we attempted to identify useful components of cucumber plant material to support its development as a medicinal resource.

As part of our ongoing search for medicinal materials in cucumber plant material, chromatographic separation and purification led to the identification of two new megastigmanes, one known megastigmane, one known carotenoid, one known lignan and three other known compounds. In the present paper, we report the isolation and structural elucidation of the new megastigmanes.

\section{Results and Discussion}

Air-dried leaves of $C$. sativus were extracted using methanol $(\mathrm{MeOH})$. The $\mathrm{MeOH}$ extract was partitioned into an ethyl acetate (EtOAc)-water mixture to furnish EtOAcsoluble and water-soluble parts. The EtOAc-soluble part was subjected to normal- and reversed-phase column chromatography and HPLC to yield compounds 1, 3, 4, 5, 6 and 7 (Fig. 1). The water-soluble part was again extracted with EtOAc, then with $n$-butanol $(\mathrm{BuOH})$, using an automatic extractor. The $n$-BuOH-soluble part was subjected to normal- and reversed-phase column chromatography and HPLC to yield compounds $\mathbf{2}$ and $\mathbf{8}$ (Fig. 1).

Compound $\mathbf{1}$ was obtained as a yellow oil with positive

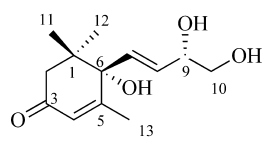

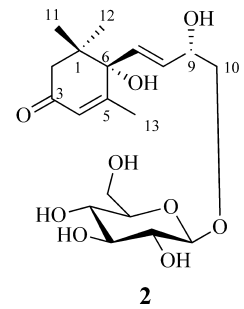

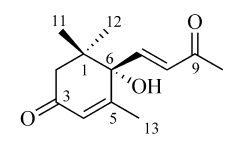

3

optical rotation $\left([\alpha]_{D}^{25}+168.53^{\circ}\right)$. Its molecular formula was determined to be $\mathrm{C}_{13} \mathrm{H}_{20} \mathrm{O}_{4}$ by high-resolution (HR)-FABMS. The ${ }^{1} \mathrm{H}-\mathrm{NMR}$ spectrum (in $\mathrm{CD}_{3} \mathrm{OD}$ ) showed signals for a vinyl proton at $\delta 5.87(1 \mathrm{H}, \mathrm{s})$, two trans olefinic protons at $\delta 5.89(1 \mathrm{H}, \mathrm{dd}, J=15.6,1.0 \mathrm{~Hz})$ and $5.79(1 \mathrm{H}, \mathrm{dd}, J=15.6$, $5.6 \mathrm{~Hz})$, two gem-dimethyl groups at $\delta 1.02(3 \mathrm{H}, \mathrm{s})$ and 1.04 $(3 \mathrm{H}, \mathrm{s})$, a methyl proton connected to a double bond at $\delta$ $1.92(3 \mathrm{H}, \mathrm{d}, J=1.2 \mathrm{~Hz})$, geminally coupled signals at $\delta 2.51$ $(1 \mathrm{H}, \mathrm{d}, J=16.8 \mathrm{~Hz})$ and $2.16(1 \mathrm{H}, \mathrm{d}, J=16.8 \mathrm{~Hz})$, one oxymethine at $\delta 4.19(1 \mathrm{H}, \mathrm{m})$, and two protons of oxymethylene at $\delta 3.50(1 \mathrm{H}, \mathrm{dd}, J=11.1,5.0 \mathrm{~Hz})$ and $3.46(1 \mathrm{H}, \mathrm{dd}, J=11.1$, $6.7 \mathrm{~Hz}$ ) (Table 1). The ${ }^{13} \mathrm{C}-\mathrm{NMR}$ spectrum of 1 exhibited a carbonyl signal at $\delta 200.7$ (s); four olefinic carbons at $\delta$ 126.9 (d), 132.1 (d), 132.2 (d) and 166.9 (s); and an oxygenated carbon signal at $\delta 80.0$ (s) (Table 2). The ${ }^{1} \mathrm{H}-{ }^{1} \mathrm{H}$ correlation spectroscopy $\left({ }^{1} \mathrm{H}-{ }^{1} \mathrm{H}\right.$ COSY $)$ spectrum showing correlations for 1 indicated the presence of partial structures (shown as bold lines (C-7-C-8-C-9-C-10) in Fig. 2). In a ${ }^{1} \mathrm{H}-{ }^{13} \mathrm{C}$ heteronuclear multiple bond coherence (HMBC) study for 1, long-range correlations were observed between the following protons and carbons: $\mathrm{H}-4$ and $\mathrm{C}-2 ; \mathrm{H}-2 \mathrm{a}, 2 \mathrm{~b}$ and C-3; H-13 and C-4; H-2a, 2b, 4, 7, 8, 13 and C-6; H-7, 8 and $\mathrm{C}-9$; and $\mathrm{H}-10 \mathrm{a}, 10 \mathrm{~b}$ and $\mathrm{C}-8$ (Fig. 2). Furthermore, acetylation of 1 with acetic anhydride in dry pyridine yielded di-O-acetate (1a), whose ${ }^{13} \mathrm{C}$-NMR spectrum showed an acetylation shift around the 9 and 10 position of 1a. These findings and comparisons of the ${ }^{1} \mathrm{H}$ - and ${ }^{13} \mathrm{C}$-NMR spectra of 1 and 1a with those of a known megastigmane led us to formulate the 3-oxo-6,9,10-trihydroxy-ionone structure of 1 (Fig. 1). The absolute configuration of C-6 of 1 was determined by application of the circular dichroism (CD) helicity rule $^{4)}$ with known (+)-dehydrovomifoliol (3). The CD spectrum of 3 showed a positive Cotton effect $(\Delta \varepsilon+27.00)$ at $243.2 \mathrm{~nm}$, and the 6-position was determined to have an $S$ configuration by the CD helicity rule. ${ }^{4}$ On the basis of this evidence, the CD spectrum of $\mathbf{1}$ exhibited a positive Cotton effect $(\Delta \varepsilon+15.79)$ at $240.8 \mathrm{~nm}$, and the 6-position was shown to have an $S$ configuration. In order to clarify the absolute stereostructure of the 9-position of $\mathbf{1}$, a modified Mosher's method was used. ${ }^{5)}$ Selective protection of the C10-OH group of 1 with $t$-butyldimethylsilyl chloride (TB$\mathrm{DMSCl})$ in dry pyridine provided the desired $t$-butyldimethylsilyl (TBDMS) ether $\mathbf{1 b}(63.9 \%)$ (Chart 1). The secondary hydroxyl group in $\mathbf{1 b}$ was treated with $R$ - and $S$ - $\alpha$ methoxy- $\alpha$-(trifluoromethyl)phenylacetic acids (MTPA), $N, N^{\prime}$-dicyclohexylcarbodiimide (DCC), and 4-(dimethyl-

Fig. 1. Structures of Compounds Isolated from Leaves of C. sativus 
Table 1. ${ }^{1} \mathrm{H}-\mathrm{NMR}$ Data for Compounds $\mathbf{1}-\mathbf{3}$

\begin{tabular}{|c|c|c|c|}
\hline Proton & 1 & 2 & 3 \\
\hline $2 \mathrm{a}$ & $2.51(1 \mathrm{H}, \mathrm{d}, J=16.8 \mathrm{~Hz})$ & $2.52(1 \mathrm{H}, \mathrm{d}, J=17.0 \mathrm{~Hz})$ & $2.59(1 \mathrm{H}, \mathrm{d}, J=18.3 \mathrm{~Hz})$ \\
\hline $2 b$ & $2.16(1 \mathrm{H}, \mathrm{d}, J=16.8 \mathrm{~Hz})$ & $2.16(1 \mathrm{H}, \mathrm{d}, J=17.0 \mathrm{~Hz})$ & $2.28(1 \mathrm{H}, \mathrm{d}, J=18.3 \mathrm{~Hz})$ \\
\hline 4 & $5.87(1 \mathrm{H}, \mathrm{s})$ & $5.88(1 \mathrm{H}, \mathrm{d}, J=1.1 \mathrm{~Hz})$ & $5.93(1 \mathrm{H}, \mathrm{s})$ \\
\hline 7 & $5.89(1 \mathrm{H}, \mathrm{dd}, J=15.6,1.0 \mathrm{~Hz})$ & $5.93(1 \mathrm{H}, \mathrm{dd}, J=15.5,1.3 \mathrm{~Hz})$ & $6.99(1 \mathrm{H}, \mathrm{d}, J=15.7 \mathrm{~Hz})$ \\
\hline 8 & $5.79(1 \mathrm{H}, \mathrm{dd}, J=15.6,5.6 \mathrm{~Hz})$ & $5.78(1 \mathrm{H}, \mathrm{dd}, J=15.5,5.6 \mathrm{~Hz})$ & $6.43(1 \mathrm{H}, \mathrm{d}, J=15.7 \mathrm{~Hz})$ \\
\hline 9 & $4.19(1 \mathrm{H}, \mathrm{m})$ & $4.40(1 \mathrm{H}, \mathrm{m})$ & \\
\hline $10 \mathrm{a}$ & $3.50(1 \mathrm{H}, \mathrm{dd}, J=11.1,5.0 \mathrm{~Hz})$ & $3.91(1 \mathrm{H}, \mathrm{dd}, J=10.1,3.8 \mathrm{~Hz})$ & $2.30(3 \mathrm{H}, \mathrm{s})$ \\
\hline $10 \mathrm{~b}$ & $3.46(1 \mathrm{H}, \mathrm{dd}, J=11.1,6.7 \mathrm{~Hz})$ & $3.46(1 \mathrm{H}, \mathrm{dd}, J=10.1,8.1 \mathrm{~Hz})$ & \\
\hline 11 & $1.04(3 \mathrm{H}, \mathrm{s})$ & $1.04(3 \mathrm{H}, \mathrm{s})$ & $1.06(3 \mathrm{H}, \mathrm{s})$ \\
\hline 12 & $1.02(3 \mathrm{H}, \mathrm{s})$ & $1.02(3 \mathrm{H}, \mathrm{s})$ & $1.01(3 \mathrm{H}, \mathrm{s})$ \\
\hline 13 & $1.92(3 \mathrm{H}, \mathrm{d}, J=1.2 \mathrm{~Hz})$ & $1.91(3 \mathrm{H}, \mathrm{d}, J=1.2 \mathrm{~Hz})$ & $1.89(3 \mathrm{H}, \mathrm{d}, J=1.5 \mathrm{~Hz})$ \\
\hline $1^{\prime}$ & & $4.29(1 \mathrm{H}, \mathrm{d}, J=7.8 \mathrm{~Hz})$ & \\
\hline $2^{\prime}$ & & $3.21(1 \mathrm{H}, \mathrm{dd}, J=9.0,7.8 \mathrm{~Hz})$ & \\
\hline $3^{\prime}$ & & $3.36(1 \mathrm{H}, \mathrm{m})$ & \\
\hline $4^{\prime}$ & & $3.27(1 \mathrm{H}$, overlap $)$ & \\
\hline $5^{\prime}$ & & $3.27(1 \mathrm{H}$, overlap $)$ & \\
\hline $6^{\prime} \mathrm{a}$ & & $3.86(1 \mathrm{H}, \mathrm{d}-\mathrm{like}, J=12.1 \mathrm{~Hz})$ & \\
\hline $6^{\prime} \mathrm{b}$ & & $3.64(1 \mathrm{H}, \mathrm{dd}, J=12.1,3.7 \mathrm{~Hz})$ & \\
\hline
\end{tabular}

ppm from TMS, in $\mathrm{CD}_{3} \mathrm{OD}, 400 \mathrm{MHz}$, room temperature.

Table 2. ${ }^{13} \mathrm{C}-\mathrm{NMR}$ Data for Compounds $\mathbf{1}-\mathbf{3}$

\begin{tabular}{rrrr}
\hline \hline Carbon & \multicolumn{1}{c}{$\mathbf{1}$} & $\mathbf{2}$ & $\mathbf{3}$ \\
\hline 1 & 42.3 & 42.4 & 42.6 \\
2 & 50.6 & 50.7 & 50.4 \\
3 & 200.7 & 200.8 & 199.9 \\
4 & 126.9 & 127.0 & 127.7 \\
5 & 166.9 & 166.9 & 164.2 \\
6 & 80.0 & 80.0 & 79.8 \\
7 & 132.2 & 132.6 & 148.0 \\
8 & 132.1 & 131.3 & 131.4 \\
9 & 73.5 & 72.0 & 200.1 \\
10 & 67.1 & 74.8 & 27.6 \\
11 & 23.4 & 23.5 & 23.5 \\
12 & 24.5 & 24.6 & 24.7 \\
13 & 19.6 & 19.7 & 19.1 \\
$1^{\prime}$ & & 104.5 & \\
$2^{\prime}$ & & 75.1 & \\
$3^{\prime}$ & & 77.8 & \\
$4^{\prime}$ & & 71.5 & \\
$5^{\prime}$ & & 77.9 & \\
$6^{\prime}$ & & 62.7 & \\
& & & \\
\hline
\end{tabular}

ppm from TMS, in $\mathrm{CD}_{3} \mathrm{OD}, 100 \mathrm{MHz}$, room temperature.

amino)pyridine (DMAP) in dry dichloromethane at room temperature to yield 9-O- $(R)$-MTPA ester $1 \mathrm{c}(60.0 \%)$ and 9$O$-(S)-MTPA ester 1d $(86.6 \%)$, respectively (Chart 1$)$. As shown in Fig. 3, the signals due to protons attached to the 2a, $2 \mathrm{~b}, 4,7,8,11,12$ and 13-positions in 1c were observed at lower fields ( $\Delta \delta$ : negative) than in $\mathbf{1 d}$, whereas the signal due to the 10-position and the TBDMS groups in 1c were observed at higher fields $(\Delta \delta$ : positive) than in 1d. Consequently, the absolute configuration at the 9-position was elucidated to be $S$. On the basis of this evidence, the structure of 1 was determined to be $(6 S, 7 E, 9 S)-6,9,10$-trihydroxy-4,7megastigmadien-3-one. We named this compound cucumegastigmane $\mathrm{I}$.

Compound 2 was obtained as a white powder (mp 96$\left.97^{\circ} \mathrm{C}\right)$ with positive optical rotation $\left([\alpha]_{\mathrm{D}}^{23}+62.9^{\circ}\right)$. Its molecular formula was determined to be $\mathrm{C}_{19} \mathrm{H}_{30} \mathrm{O}_{9}$ by HR-FABMS. The ${ }^{1} \mathrm{H}$ - and ${ }^{13} \mathrm{C}$-NMR spectral data (in $\mathrm{CD}_{3} \mathrm{OD}$ ) were similar to those of $\mathbf{1}$, except for the difference in the chemi-
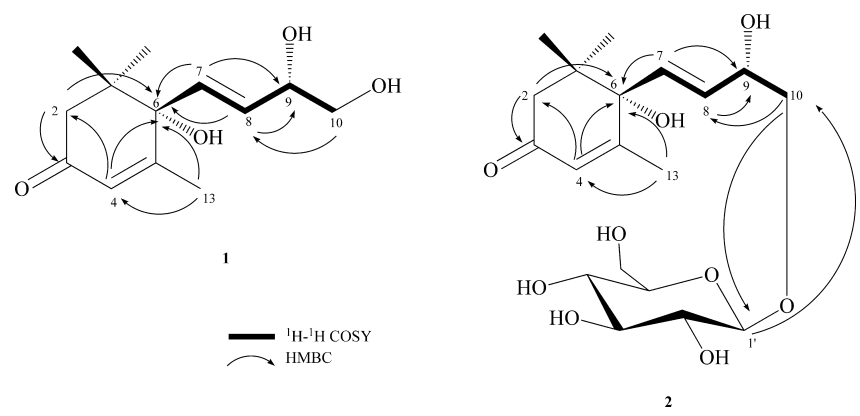

Fig. 2. ${ }^{1} \mathrm{H}-{ }^{1} \mathrm{H}$ COSY and HMBC Correlations of $\mathbf{1}$ and $\mathbf{2}$

cal shifts of the sugar, which was identified as glucose by these spectral data and results of described later. The ${ }^{1} \mathrm{H}-$ NMR spectrum revealed anomeric signals of $\beta$-glucose at $\delta$ $4.29(1 \mathrm{H}, \mathrm{d}, J=7.8 \mathrm{~Hz})$ (Table 1). The $\beta$-glucose was localized at $\mathrm{C}-10$ given the downfield shift of this carbon signal at $\delta 74.8$ (Table 2), as confirmed by the HMBC spectrum (Fig. 2). Compound 2 was identified as being a megastigmane glucoside by MS, UV and NMR spectroscopy. ${ }^{1} \mathrm{H}-{ }^{1} \mathrm{H}$ COSY, ${ }^{13} \mathrm{C}-{ }^{1} \mathrm{H}$ COSY and $\mathrm{HMBC}$ spectral data were essentially identical to the published data for natural parvispinoside $\mathrm{C}$ $\left([\alpha]_{\mathrm{D}}^{22}-8.9^{\circ}\right),{ }^{6}{ }^{6}$ although there was a disparity in the optical rotation values. The stereochemical structure at the 9-position of parvispinoside $\mathrm{C}$ has been not determined. Compound 2 was hydrolyzable by $\beta$-glucosidase to an aglycone and D-glucose. The absolute structure of aglycone was expected to be the same as that of $\mathbf{1}$, as both were isolated from the same materials. The configuration of the D-glucose was identified by the positive optical rotation of the sugar part. Thus, the structure of compound $\mathbf{2}$ was determined to be $(6 S, 7 E, 9 S)-6,9,10$-trihydroxy-4,7-megastigmadien-3-one 10 $O$ - $\beta$-D-glucopyranoside. We named this compound cucumegastigmane II.

Compound $\mathbf{3}$ was obtained as a yellow oil with positive optical rotation $\left([\alpha]_{\mathrm{D}}^{28}+139.0^{\circ}\right)$. Its molecular formula was determined to be $\mathrm{C}_{13} \mathrm{H}_{18} \mathrm{O}_{3}$ by HR-EI-MS. Compound $\mathbf{3}$ was identified as a megastigmane by MS, UV, CD, and NMR spectroscopy. ${ }^{1} \mathrm{H}-{ }^{1} \mathrm{H}$ COSY, ${ }^{13} \mathrm{C}-{ }^{1} \mathrm{H}$ COSY and HMBC spec- 


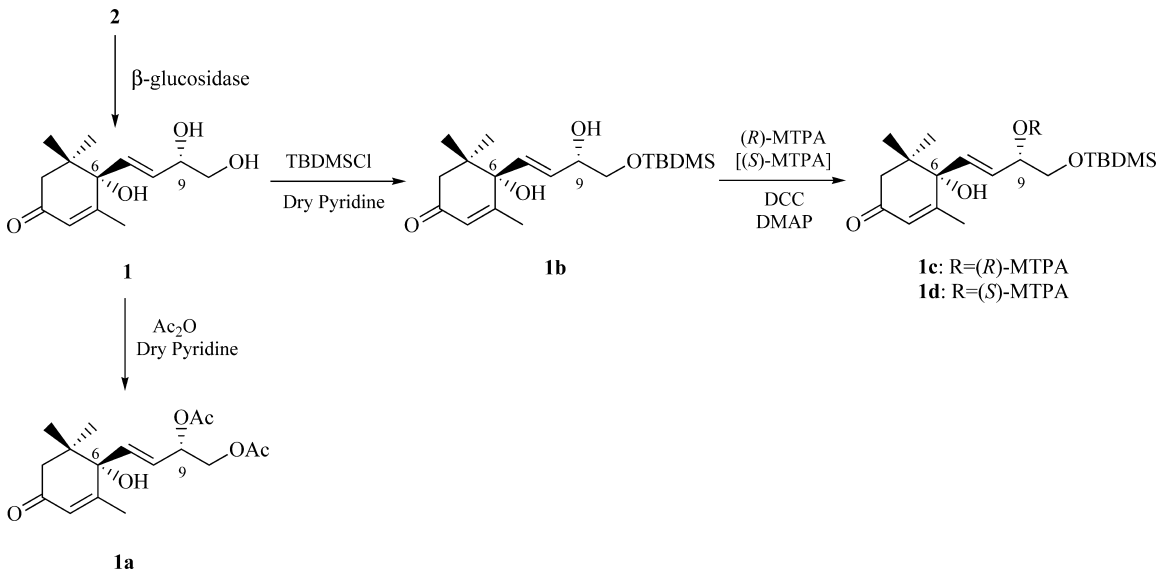

Chart 1

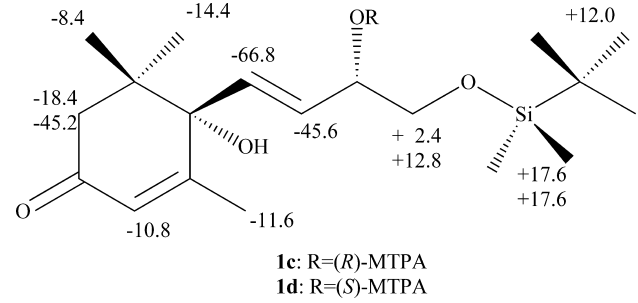

Fig. 3. Results of the Modified Mosher's Method for 1c and 1d

The $\Delta \delta$ values are in $\mathrm{Hz}(\delta S-\delta R, 400 \mathrm{MHz})$

tral data were essentially identical to the published data for natural $(+)$-dehydrovomifoliol $\left([\alpha]_{\mathrm{D}}^{20}+134.4^{\circ}\right)$, which is isolated from the aerial parts of Beta vulgaris var. cicla (Chenopodiaceae). ${ }^{7)}$

In addition, other five known compounds were identified by comparison of their spectroscopic data (NMR, UV, IR, MS, CD and optical rotation) with reported values. These compounds were lutein $(4),{ }^{8)}(+)-(1 R, 2 S, 5 R, 6 S)-2,6-d i-\left(4^{\prime}-\right.$ hydroxyphenyl)-3,7-dioxabicyclo $(3,3,0)$ octane (5), ${ }^{9,10)}$ indole-3-aldehyde (6), ${ }^{11)}$ indole-3-carboxylic acid (7), ${ }^{12}$ and adenosine $(\mathbf{8}),{ }^{13)}$ respectively.

\section{Experimental}

Instruments Melting points were determined by using a Yanako micromelting point apparatus, and were left uncorrected. UV spectra and optical rotation data were obtained using a Shimadzu UV 1600 spectrophotometer and a Horiba SEPA-300 digital polarimeter, respectively. EI-MS and FABMS data were obtained by using a JEOL JMS-700 mass spectrometer. CD spectra were obtained in $\mathrm{MeOH}$ by using a Jasco J-820 spectrometer. ${ }^{1} \mathrm{H}-$ and ${ }^{13} \mathrm{C}-\mathrm{NMR}$ spectra were obtained by using a JEOL JNM-AL 400 spectrometer with tetramethylsilane as an internal standard. TLC was performed using silica gel $60 \mathrm{~F}_{254}$ TLC plates (Merck) and RP-18 $\mathrm{F}_{254 \mathrm{~S}}$ TLC plates (Merck). Silica gel $60 \mathrm{~N}(100-200 \mu \mathrm{m}$; Kanto Chemical) was used for silica gel open column chromatography. HPLC separation was carried out in a COSMOSIL $5 \mathrm{C}_{18}$-ARII column (Nacalai) with a LC-20AT dual pump (Shimadzu), monitored by a SPD-20A detector (Shimadzu) at $254 \mathrm{~nm}$, and in an AQUASIL SS-852N column (SSC) with a PRP-60 pump (Oyo-Bunko), monitored by a RID-10A detector (Shimadzu).

Plant Materials Leaves of $C$. sativus were collected during September and October 2004 in Takaoka, Miyazaki, Japan. The voucher specimen is deposited in the Department of Natural Medicine \& Phytochemistry, Meiji Pharmaceutical University.

Extraction and Isolation Air-dried powdered leaves of $C$. sativus $(4.5 \mathrm{~kg})$ were extracted using $\mathrm{MeOH}(1351$ for $24 \mathrm{~h} \times 4$ times $)$ at room temperature. The $\mathrm{MeOH}$ extract was concentrated under reduced pressure to yield $661.8 \mathrm{~g}$. The $\mathrm{MeOH}$ extract $(645.1 \mathrm{~g})$ was suspended in water and partitioned with EtOAc. The EtOAc-soluble part $(126.9 \mathrm{~g})$ was subjected to column chromatography on silica gel and eluted stepwise using $n$ hexane-EtOAc $(10: 1,5: 1,2: 1,1: 1,1: 2,1: 5)$, EtOAc, EtOAc-MeOH $(1: 1)$ and $\mathrm{MeOH}$ to yield 8 corresponding fractions (A1-A8). Fraction A5 (7.8 g) was further separated by Diaion HP-20 column chromatography and eluted stepwise using $\mathrm{MeOH}-\mathrm{H}_{2} \mathrm{O}(1: 2,1: 1,2: 1), \mathrm{MeOH}$, acetone- $\mathrm{MeOH}$ $(1: 1)$ and acetone to yield 7 corresponding fractions. Subfraction A5-3 ( $1.1 \mathrm{~g})$ was further separated by Sephadex LH-20 column chromatography using $\mathrm{MeOH}$ to yield 7 corresponding fractions. Subfraction A5-2 $\left(434.9 \mathrm{mg}\right.$ ) was subjected to preparative HPLC [COSMOSIL 5C $\mathrm{C}_{18}$-ARII column $\phi 20 \times 250 \mathrm{~mm}, 50 \% \mathrm{CH}_{3} \mathrm{CN}$ aq., $2.0 \mathrm{ml} / \mathrm{min}$, UV detection $\left.(254 \mathrm{~nm})\right]$, which yielded 4 fractions. Subfraction A5-2-2 $(83.9 \mathrm{mg})$ was subjected to purified HPLC [COSMOSIL 5C 18 -ARII column $\phi 10 \times 250 \mathrm{~mm}, 24 \%$ $\mathrm{CH}_{3} \mathrm{CN}$ aq., $2.0 \mathrm{ml} / \mathrm{min}$, UV detection $\left.(254 \mathrm{~nm})\right]$ to yield compounds 3 $(18.9 \mathrm{mg})$ and $7(14.5 \mathrm{mg})$. Subfraction A5-5-4 $(192.3 \mathrm{mg})$ was purified by column chromatography on silica gel using mixtures of $n$-hexane, EtOAc and $\mathrm{MeOH}$ to yield compound 4 (58.6 mg). Subfraction A5-3-5 $(9.3 \mathrm{mg})$ was subjected to purified HPLC [COSMOSIL 5C 18 -ARII column $\phi$ $10 \times 250 \mathrm{~mm}, 46 \% \mathrm{CH}_{3} \mathrm{CN}$ aq., $2.0 \mathrm{ml} / \mathrm{min}$, UV detection $\left.(254 \mathrm{~nm})\right]$ to yield compound $5(1.3 \mathrm{mg})$. Subfraction A5-2-3 $(23.7 \mathrm{mg})$ was subjected to purified HPLC [COSMOSIL 5C $\mathrm{C}_{18}$-ARII column $\phi 10 \times 250 \mathrm{~mm}, 28 \% \mathrm{CH}_{3} \mathrm{CN}$ aq., $2.0 \mathrm{ml} / \mathrm{min}$, UV detection $(254 \mathrm{~nm})]$ to yield compound $6(5.4 \mathrm{mg})$. Fraction A7 $(26.5 \mathrm{~g})$ was further separated by Diaion HP-20 column chromatography and eluted stepwise with $\mathrm{MeOH}-\mathrm{H}_{2} \mathrm{O}(1: 2,1: 1,2: 1,5: 1), \mathrm{MeOH}$ acetone and EtOAc to yield 10 corresponding fractions. Subfraction A7-3 $\left(418.4 \mathrm{mg}\right.$ ) was subjected to preparative HPLC [COSMOSIL 5C $_{18}$-ARII column $\phi 10 \times 250 \mathrm{~mm}, 20 \% \mathrm{CH}_{3} \mathrm{CN}$ aq., $1.0 \mathrm{ml} / \mathrm{min}$, UV detection $\left.(254 \mathrm{~nm})\right]$ to yield compound $1(27.6 \mathrm{mg})$. The water-soluble part $(423.1 \mathrm{~g})$ was extracted with EtOAc using an automatic extractor to yield another EtOAc-soluble part $(93.7 \mathrm{~g})$. The water-soluble part was then extracted with $n$ - $\mathrm{BuOH}$ using an automatic extractor. The $n$ - $\mathrm{BuOH}$-soluble part $(37.2 \mathrm{~g})$ was subjected to column chromatography on silica gel and eluted stepwise using $n$ hexane-EtOAc $(1: 1,1: 2,1: 5)$, EtOAc, EtOAc-MeOH $(10: 1,5: 1,2: 1$, $1: 1,1: 2,1: 6,1: 10)$ and $\mathrm{MeOH}$ to yield 8 corresponding fractions (B1B11). Fraction B8 (3.4g) was further separated by Diaion HP-2MG column chromatography and eluted stepwise using $\mathrm{H}_{2} \mathrm{O}, \mathrm{MeOH}-\mathrm{H}_{2} \mathrm{O}(1: 4,2: 3$, $3: 2,2: 3,4: 1), \mathrm{MeOH}$ and acetone to yield 4 corresponding fractions. Subfraction B8-2 (1.3 g) was subjected to preparative HPLC [AQUASIL SS$852 \mathrm{~N}$ column $\phi 20 \times 250 \mathrm{~mm}$, EtOAc : $\mathrm{MeOH}: \mathrm{H}_{2} \mathrm{O}(20: 2: 1), 7.0 \mathrm{ml} / \mathrm{min}$, refractive index (RI) detection] to yield 6 corresponding fractions. Subfraction B8-2-3 (132.7 mg) was subjected to preparative HPLC [COSMOSIL $5 \mathrm{C}_{18}$-ARII column $\phi 10 \times 250 \mathrm{~mm}, 20 \% \mathrm{CH}_{3} \mathrm{CN}$ aq., $1.0 \mathrm{ml} / \mathrm{min}$, UV detection $(254 \mathrm{~nm})$ ] to yield compounds $2(49.3 \mathrm{mg})$ and $\mathbf{8}(10.2 \mathrm{mg})$.

Cucumegastigmane I (1): Yellow oil, $[\alpha]_{\mathrm{D}}^{25}+168.53^{\circ}(c=0.075, \mathrm{MeOH})$ UV $\lambda_{\max }(\mathrm{MeOH}) \mathrm{nm}(\log \varepsilon): 237.5$ (4.08). CD $\left(c=7.69 \times 10^{-5} \mathrm{M}, \mathrm{MeOH}\right)$ $\Delta \varepsilon$ (nm): +15.79 (240.8), -0.85 (316.8). FAB-MS $\mathrm{m} / \mathrm{z}$ (pos.): 241 $[\mathrm{M}+\mathrm{H}]^{+}, 223,205,121,115$. HR-FAB-MS $m / z: 241.1447[\mathrm{M}+\mathrm{H}]^{+}$(Calcd for $\left.\mathrm{C}_{13} \mathrm{H}_{21} \mathrm{O}_{4}: 241.1440\right)$. NMR data: see Tables 1 and 2 .

Acetylation of 1 A solution of $1(3.9 \mathrm{mg}, 16.25 \mu \mathrm{mol})$ in dry pyridine $(0.1 \mathrm{ml})$ was cooled with ice water, and acetic anhydride $(0.05 \mathrm{ml})$ was added dropwise. The reaction mixture was stirred for 210 min under an Ar atmosphere. After dilution with water $(10 \mathrm{ml})$, the mixture was extracted with chloroform $(10 \mathrm{ml} \times 3)$ and chloroform $/ n-\mathrm{BuOH}(2: 1,10 \mathrm{ml} \times 3)$. The combined extracts were washed with $5 \% \mathrm{NaHCO}_{3}(10 \mathrm{ml})$, dried with $\mathrm{Na}_{2} \mathrm{SO}_{4}$, 
and concentrated in vacuo to yield a residue. Chromatography of the residue on a silica gel $(40 \mathrm{ml})$ column with $n$-hexane-EtOAc as the eluent yielded 1a $(5.0 \mathrm{mg}, 95.0 \%)$ as a yellow oil.

Cucumegastigmane I Diacetate (1a): Yellow oil, $[\alpha]_{\mathrm{D}}^{29}+75.53^{\circ}(c=0.094$, $\left.\mathrm{CHCl}_{3}\right)$. UV $\lambda_{\text {max }}\left(\mathrm{CHCl}_{3}\right) \mathrm{nm}(\log \varepsilon): 241.0$ (3.74). FAB-MS $m / z$ (pos.): 325 $[\mathrm{M}+\mathrm{H}]^{+}, 265,205,121$. HR-FAB-MS $m / z: 325.1643[\mathrm{M}+\mathrm{H}]^{+}($Calcd for $\left.\mathrm{C}_{17} \mathrm{H}_{25} \mathrm{O}_{6}: 325.1652\right)$. ${ }^{1} \mathrm{H}-\mathrm{NMR}\left(\mathrm{CDCl}_{3}, 400 \mathrm{MHz}\right) \delta: 5.91(1 \mathrm{H}$, d-like $J=1.2 \mathrm{~Hz}, \mathrm{H}-4), 5.91(1 \mathrm{H}, \mathrm{d}, J=15.6 \mathrm{~Hz}, \mathrm{H}-7), 5.77(1 \mathrm{H}, \mathrm{dd}, J=15.6$ $6.5 \mathrm{~Hz}, \mathrm{H}-8), 5.51$ (1H, m, H-9), 4.23 (1H, dd, $J=11.7,4.0 \mathrm{~Hz}, \mathrm{H}-10 \mathrm{a}), 4.13$ $(1 \mathrm{H}, \mathrm{dd}, J=11.7,6.6 \mathrm{~Hz}, \mathrm{H}-10 \mathrm{~b}), 2.44(1 \mathrm{H}, \mathrm{d}, J=17.1 \mathrm{~Hz}, \mathrm{H}-2 \mathrm{a}), 2.27(1 \mathrm{H}$, d, $J=17.1 \mathrm{~Hz}, \mathrm{H}-2 \mathrm{~b}), 2.09$ (3H, s, 10-OAc), 2.06 (3H, s, 9-OAc), $1.86(3 \mathrm{H}$ d, $J=1.5 \mathrm{~Hz}, \mathrm{H}-13), 1.08$ (3H, s, H-11), 0.99 (3H, s, H-12). ${ }^{13} \mathrm{C}-\mathrm{NMR}$ $\left(\mathrm{CDCl}_{3}, 100 \mathrm{MHz}\right) \quad \delta: 197.3(\mathrm{C}-3), 170.4 \quad\left(9-\mathrm{OCOCH}_{3}\right), 169.8 \quad(10$ $\mathrm{OCOCH}_{3}$ ), 161.4 (C-5), 134.5 (C-7), 127.2 (C-4), 126.0 (C-8), 79.0 (C-6), 71.5 (C-9), 64.7 (C-10), 49.6 (C-2), 41.1 (C-1), 24.1 (C-12), 22.9 (C-11) $21.1\left(10-\mathrm{OCO}_{\mathbf{C H}}\right), 20.8\left(9-\mathrm{OCOC} \mathrm{H}_{3}\right), 18.8(\mathrm{C}-13)$.

Treatment with TBDMSCl of $1^{14)}$ A solution of $1(7.0 \mathrm{mg}, 29.2 \mu \mathrm{mol})$ in dry pyridine $(0.2 \mathrm{ml})$ was stirred under an Ar atmosphere. Then, TBDM$\mathrm{SCl}(73.0 \mu \mathrm{mol}, 1 \mathrm{~m}$ in dichloromethane $)$ was added dropwise. The reaction mixture was stirred for $6 \mathrm{~h}$, after which time $5 \mathrm{ml}$ of a saturated aqueous $\mathrm{NH}_{4} \mathrm{Cl}$ solution $(5 \mathrm{ml})$ was added. The aqueous soluble part was extracted with chloroform $(5 \mathrm{ml} \times 3)$ and chloroform $/ n-\mathrm{BuOH}(2: 1,5 \mathrm{ml} \times 3)$. The combined extracts were dried with $\mathrm{Na}_{2} \mathrm{SO}_{4}$, and concentrated in vacuo to yield a residue. Chromatography of the residue on a silica gel $(40 \mathrm{ml}) \mathrm{col}-$ umn with $n$-hexane-EtOAc as the eluent yielded 1 b $(6.6 \mathrm{mg}, 63.9 \%)$ as a yellow oil.

10-TBDMS-Cucumegastigmane I (1b): Yellow oil, $[\alpha]_{\mathrm{D}}^{27}+128.24^{\circ}$ $\left(c=0.170, \mathrm{CHCl}_{3}\right)$. UV $\lambda_{\max }\left(\mathrm{CHCl}_{3}\right) \mathrm{nm}(\log \varepsilon): 241.0(4.02)$. FAB-MS $\mathrm{m} / \mathrm{z}$ (pos.): $355[\mathrm{M}+\mathrm{H}]^{+}, 337,205,121,73$. HR-FAB-MS $m / z: 355.2312$ $[\mathrm{M}+\mathrm{H}]^{+}$(Calcd for $\left.\mathrm{C}_{19} \mathrm{H}_{35} \mathrm{O}_{4} \mathrm{Si}: 355.2306\right) .{ }^{1} \mathrm{H}-\mathrm{NMR}\left(\mathrm{CDCl}_{3}, 400 \mathrm{MHz}\right) \delta$ : $5.92(1 \mathrm{H}, \mathrm{dd}, J=15.6,1.2 \mathrm{~Hz}, \mathrm{H}-7), 5.91(1 \mathrm{H}, \mathrm{d}, J=1.5 \mathrm{~Hz}, \mathrm{H}-4), 5.77(1 \mathrm{H}$ dd, $J=15.6,5.1 \mathrm{~Hz}, \mathrm{H}-8), 4.25(1 \mathrm{H}, \mathrm{m}, \mathrm{H}-9), 3.66(1 \mathrm{H}, \mathrm{dd}, J=10.0,3.9 \mathrm{~Hz}$, $\mathrm{H}-10 \mathrm{a}), 3.44$ (1H, dd, $J=10.0,7.3 \mathrm{~Hz}, \mathrm{H}-10 \mathrm{~b}), 2.46(1 \mathrm{H}, \mathrm{d}, J=17.1 \mathrm{~Hz}, \mathrm{H}$ 2a), $2.24(1 \mathrm{H}, \mathrm{dd}, J=17.1,1.0 \mathrm{~Hz}, \mathrm{H}-2 \mathrm{~b}), 1.89(3 \mathrm{H}, \mathrm{d}, J=1.5 \mathrm{~Hz}, \mathrm{H}-13)$, $1.08(3 \mathrm{H}, \mathrm{s}, \mathrm{H}-11), 1.02(3 \mathrm{H}, \mathrm{s}, \mathrm{H}-12), 0.90\left(9 \mathrm{H}, \mathrm{s},-\mathrm{CMe}_{3}\right), 0.08(6 \mathrm{H}, \mathrm{s}$, $\left.-\mathrm{SiMe}_{2}\right) .{ }^{13} \mathrm{C}-\mathrm{NMR}\left(\mathrm{CDCl}_{3}, 100 \mathrm{MHz}\right) \delta$ : 197.4 (C-3), 162.0 (C-5), 131.2 (C-7), 129.9 (C-8), 126.7 (C-4), 79.1 (C-6), 71.8 (C-9), 66.8 (C-10), 49.6 (C-2), 41.0 (C-1), 25.8 (- $\mathrm{CMe}_{3}$ ), 24.0 (C-12), 22.8 (C-11), 18.8 (C-13), 18.2 $\left(-\mathrm{CMe}_{3}\right),-5.3,-5.4\left(-\mathrm{SiMe}_{2}\right)$.

Preparation of the $(R)$ - and $(S)$-MTPA Derivatives $1 \mathrm{c}$ and $1 \mathrm{~d}$ from $\mathbf{1 b}^{15)}(R)$-MTPA working solution $((R)$-MTPA $27.8 \mathrm{mg}$ and DCC $29.1 \mathrm{mg}$ in $0.5 \mathrm{ml}$ of dry dichloromethane) was prepared. Compound $\mathbf{1 b}(2.8 \mathrm{mg}$, $7.9 \mu \mathrm{mol})$ and DMAP $(0.9 \mathrm{mg})$ were dissolved in dry dichloromethane $(0.5 \mathrm{ml})$ and stirred at room temperature for $30 \mathrm{~min}$. Then, $(R)$-MTPA working solution was added and stirred at room temperature for $1 \mathrm{~h}$. After the addition of $5 \mathrm{ml}$ each of water and dichloromethane, the solution was washed successively with $5 \% \mathrm{HCl}(5 \mathrm{ml})$, saturated $\mathrm{NaHCO}_{3}(5 \mathrm{ml})$ and brine $(5 \mathrm{ml})$. The organic soluble part was dried with $\mathrm{Na}_{2} \mathrm{SO}_{4}$, and concentrated in vacuo to yield a residue. Chromatography of the residue on a silica gel $(40 \mathrm{ml}) \mathrm{col}-$ umn using $n$-hexane-EtOAc as the eluent yielded $1 \mathrm{c}(2.7 \mathrm{mg}, 60.0 \%)$ as a colorless oil. Using a similar procedure, 1 d $(4.6 \mathrm{mg}, 86.6 \%)$ was prepared from $1 \mathbf{b}(3.3 \mathrm{mg}, 9.3 \mu \mathrm{mol})$ with $(S)$-MTPA $(33.1 \mathrm{mg})$, DCC $(25.9 \mathrm{mg})$ and DMAP (1.3 mg).

10-TBDMS-Cucumegastigmane I 9- $O-(R)-\mathrm{MTPA}$ Ester $(1 \mathrm{c})$ : Colorless oil, $[\alpha]_{\mathrm{D}}^{29}+42.73^{\circ}\left(c=0.044, \mathrm{CHCl}_{3}\right)$. UV $\lambda_{\max }\left(\mathrm{CHCl}_{3}\right) \mathrm{nm}(\log \varepsilon): 241.0$ (3.68). FAB-MS $m / z$ (pos.): $571[\mathrm{M}+\mathrm{H}]^{+}, 337,205,189,121$, 73. HR-FABMS $m / z$ : $571.2706[\mathrm{M}+\mathrm{H}]^{+}$(Calcd for $\left.\mathrm{C}_{29} \mathrm{H}_{42} \mathrm{O}_{6} \mathrm{~F}_{3} \mathrm{Si}: 571.2704\right) .{ }^{1} \mathrm{H}-\mathrm{NMR}$ $\left(\mathrm{CDCl}_{3}, 400 \mathrm{MHz}\right) \delta: 7.52-7.34(5 \mathrm{H}, \mathrm{m},-\mathrm{Ph}), 5.96(1 \mathrm{H}, \mathrm{d}, J=15.4 \mathrm{~Hz}, \mathrm{H}-$ 7), 5.89 (1H, s, H-4), 5.85 (1H, dd, $J=15.4,7.0 \mathrm{~Hz}, \mathrm{H}-8), 5.53$ (1H, m, H-9), 3.75 (1H, dd, $J=10.9,6.1 \mathrm{~Hz}, \mathrm{H}-10 \mathrm{a}), 3.69$ (1H, dd, $J=10.9,4.8 \mathrm{~Hz}, \mathrm{H}-10 \mathrm{~b})$, $3.50(3 \mathrm{H}, \mathrm{d}, J=1.0 \mathrm{~Hz},-\mathrm{OMe}), 2.39(1 \mathrm{H}, \mathrm{d}, J=17.0 \mathrm{~Hz}, \mathrm{H}-2 \mathrm{a}), 2.24(1 \mathrm{H}, \mathrm{d}$, $J=17.0 \mathrm{~Hz}, \mathrm{H}-2 \mathrm{~b}), 1.85$ (3H, d, $J=1.2 \mathrm{~Hz}, \mathrm{H}-13), 1.06$ (3H, s, H-11), 0.94 $(3 \mathrm{H}, \mathrm{s}, \mathrm{H}-12), 0.84\left(9 \mathrm{H}, \mathrm{s},-\mathrm{CMe}_{3}\right), 0.01\left(6 \mathrm{H}, \mathrm{s},-\mathrm{SiMe}_{2}\right)$.

10-TBDMS-Cucumegastigmane I 9- $O$ - $(S)$-MTPA Ester (1d): Colorless oil, $[\alpha]_{\mathrm{D}}^{28}+70.94^{\circ}\left(c=0.064, \mathrm{CHCl}_{3}\right)$. UV $\lambda_{\max }\left(\mathrm{CHCl}_{3}\right) \mathrm{nm}(\log \varepsilon): 241.0$ (4.12). FAB-MS $m / z$ (pos.): $571[\mathrm{M}+\mathrm{H}]^{+}, 337,205,189,121,73$. HR-FABMS $m / z$ : $571.2706[\mathrm{M}+\mathrm{H}]^{+}$(Calcd for $\left.\mathrm{C}_{29} \mathrm{H}_{42} \mathrm{O}_{6} \mathrm{~F}_{3} \mathrm{Si}: 571.2704\right) .{ }^{1} \mathrm{H}-\mathrm{NMR}$ $\left(\mathrm{CDCl}_{3}, 400 \mathrm{MHz}\right) \delta: 7.54-7.32(5 \mathrm{H}, \mathrm{m},-\mathrm{Ph}), 5.87(1 \mathrm{H}, \mathrm{s}, \mathrm{H}-4), 5.79(1 \mathrm{H}$, d, $J=15.6 \mathrm{~Hz}, \mathrm{H}-7), 5.74(1 \mathrm{H}, \mathrm{d}, J=15.6 \mathrm{~Hz}, \mathrm{H}-8), 5.59(1 \mathrm{H}, \mathrm{m}, \mathrm{H}-9), 3.76$ $(1 \mathrm{H}, \mathrm{dd}, J=9.8,5.4 \mathrm{~Hz}, \mathrm{H}-10 \mathrm{a}), 3.72$ (1H, dd, $J=9.8,3.4 \mathrm{~Hz}, \mathrm{H}-10 \mathrm{~b}), 3.58$ $(3 \mathrm{H}, \mathrm{d}, J=1.0 \mathrm{~Hz},-\mathrm{OMe}), 2.28(1 \mathrm{H}, \mathrm{d}, J=17.0 \mathrm{~Hz}, \mathrm{H}-2 \mathrm{a}), 2.19(1 \mathrm{H}, \mathrm{d}$, $J=17.0 \mathrm{~Hz}, \mathrm{H}-2 \mathrm{~b}), 1.82$ (3H, d, $J=1.5 \mathrm{~Hz}, \mathrm{H}-13), 1.04$ (3H, s, H-11), 0.91
(3H, s, H-12), 0.87 (9H, s, $\left.-\mathrm{CMe}_{3}\right), 0.05\left(6 \mathrm{H}, \mathrm{s},-\mathrm{SiMe}_{2}\right)$

Cucumegastigmane II (2): White powder, mp $96-97^{\circ} \mathrm{C},[\alpha]_{\mathrm{D}}^{23}+62.89^{\circ}$ $(c=0.698, \mathrm{MeOH})$. UV $\lambda_{\max }(\mathrm{MeOH}) \mathrm{nm}(\log \varepsilon): 235.5$ (3.94). CD $\left(c=6.76 \times 10^{-5} \mathrm{M}, \mathrm{MeOH}\right) \Delta \varepsilon(\mathrm{nm}):+11.09$ (239.6), -0.60 (319.8). FABMS $m / z$ (pos.): $403[\mathrm{M}+\mathrm{H}]^{+}$, (neg.): $401[\mathrm{M}-\mathrm{H}]^{-}$. HR-FAB-MS $m / z$ (pos.): $403.1967[\mathrm{M}+\mathrm{H}]^{+}\left(\right.$Calcd for $\mathrm{C}_{19} \mathrm{H}_{31} \mathrm{O}_{9}:$ 403.1968). NMR data: see Tables 1 and 2 .

Enzymatic Hydrolysis of $\mathbf{2}^{16,17)}$ A solution of $\mathbf{2}(7.4 \mathrm{mg})$ in acetate buffer $(\mathrm{pH} 4.4,2.0 \mathrm{ml})$ was treated with $\beta$-glucosidase (Oriental Yeast, $8.1 \mathrm{mg}$ ) and the solution was left standing at $38^{\circ} \mathrm{C}$ for $20 \mathrm{~h}$. The reaction solution was poured into water $(5 \mathrm{ml})$ and the whole was extracted with EtOAc $(5 \mathrm{ml} \times 5)$. The combined EtOAc extracts were dried with $\mathrm{MgSO}_{4}$, and concentrated in vacuo to yield 2 a $(2.2 \mathrm{mg}, 49.7 \%)$ as a yellow oil. The watersoluble part after neutralization using Amberlite (IRA-400, Organo) and evaporation was shown to contain D-glucose, identified by TLC using a 2butanone-acetic acid- $\mathrm{H}_{2} \mathrm{O}(3: 1: 1)$ solvent system. Chromatography of the water-soluble part on a silica gel $(40 \mathrm{ml})$ column with EtOAc-MeOH as the eluent yielded D-glucose $(1.5 \mathrm{mg}, 45.3 \%)$. D-Glucose: $[\alpha]_{\mathrm{D}}^{25}+28.58^{\circ}$ ( $c=0.099, \mathrm{H}_{2} \mathrm{O}, 24 \mathrm{~h}$ after being dissolved in $\mathrm{H}_{2} \mathrm{O}$ ).

Aglycone of Cucumegastigmane II (2a): Yellow oil, $[\alpha]_{\mathrm{D}}^{25}+144.53^{\circ}$ $(c=0.075, \mathrm{MeOH}) . \mathrm{UV} \lambda_{\max }(\mathrm{MeOH}) \mathrm{nm}(\log \varepsilon): 236.5$ (4.12). CD $\left(c=2.92 \times 10^{-5} \mathrm{M}, \mathrm{MeOH}\right) \Delta \varepsilon(\mathrm{nm}):+12.39$ (240.2), -0.76 (328.4). FABMS $m / z$ (pos.): $241[\mathrm{M}+\mathrm{H}]^{+}, 207,115$. HR-FAB-MS $m / z: 241.1453$ $[\mathrm{M}+\mathrm{H}]^{+}$(Calcd for $\left.\mathrm{C}_{13} \mathrm{H}_{21} \mathrm{O}_{4}: 241.1440\right) .{ }^{1} \mathrm{H}-\mathrm{NMR}\left(\mathrm{CD}_{3} \mathrm{OD}, 400 \mathrm{MHz}\right) \delta$ : $5.89(1 \mathrm{H}, \mathrm{dd}, J=15.7,1.2 \mathrm{~Hz}, \mathrm{H}-7), 5.88(1 \mathrm{H}, \mathrm{s}, \mathrm{H}-4), 5.78(1 \mathrm{H}, \mathrm{dd}, J=15.7$, $5.5 \mathrm{~Hz}, \mathrm{H}-8), 4.19$ (1H, m, H-9), 3.50 (1H, dd, $J=11.0,4.9 \mathrm{~Hz}, \mathrm{H}-10 \mathrm{a}), 3.46$ $(1 \mathrm{H}, \mathrm{dd}, J=11.0,6.6 \mathrm{~Hz}, \mathrm{H}-10 \mathrm{~b}), 2.50(1 \mathrm{H}, \mathrm{d}, J=16.8 \mathrm{~Hz}, \mathrm{H}-2 \mathrm{a}), 2.15(1 \mathrm{H}$, d, $J=16.8 \mathrm{~Hz}, \mathrm{H}-2 \mathrm{~b}), 1.92(3 \mathrm{H}, \mathrm{d}, J=1.2 \mathrm{~Hz}, \mathrm{H}-13), 1.04(3 \mathrm{H}, \mathrm{s}, \mathrm{H}-11), 1.02$ $(3 \mathrm{H}, \mathrm{s}, \mathrm{H}-12) .{ }^{13} \mathrm{C}-\mathrm{NMR}\left(\mathrm{CD}_{3} \mathrm{OD}, 100 \mathrm{MHz}\right) \delta: 200.7$ (C-3), 166.9 (C-5), 132.3 (C-7), 132.1 (C-8), 126.9 (C-4), 80.0 (C-6), 73.5 (C-9), 67.2 (C-10), 50.7 (C-2), 42.3 (C-1), 24.5 (C-12), 23.4 (C-11), 19.6 (C-13).

(+)-Dehydrovomifoliol (3): Yellow oil, $[\alpha]_{\mathrm{D}}^{28}+138.96^{\circ} \quad(c=0.424$, $\mathrm{MeOH})$. UV $\lambda_{\max }(\mathrm{MeOH}) \mathrm{nm}(\log \varepsilon): 238.0$ (4.19). CD $\left(c=3.15 \times 10^{-5} \mathrm{M}\right.$, $\mathrm{MeOH}) \Delta \varepsilon(\mathrm{nm}):+27.00$ (243.2). EI-MS $m / z$ (rel. int. \%): 222 (1) $[\mathrm{M}]^{+}$, 166 (25), 124 (100). HR-EI-MS $m / z$ : $222.1251[\mathrm{M}]^{+}$(Calcd for $\mathrm{C}_{13} \mathrm{H}_{18} \mathrm{O}_{3}$ : 222.1256). NMR data: see Tables 1 and 2.

\section{References}

1) "Chuyaku-daijiten" Shanghai Technology, Shogakukan Press, Tokyo, 1985, pp. 105-120.

2) Enslin P. R., Hugo J. M., Norton K. B., Rivett D. E. A., J. Chem. Soc., 1960, 4787-4791 (1960).

3) McNally D. J., Wurms K. V., Labbe C., Quideau S., Belanger R. R., J. Nat. Prod., 66, 1280-1283 (2003).

4) Weiss G., Koreeda M., Nakanishi K., J. Chem. Soc. Chem. Commun., 1972, 565-566 (1972).

5) Ohtani I., Kusumi., Kashman Y., Kakisawa H., J. Am. Chem. Soc., 113 4092-4096 (1991).

6) Perrone A., Plaza A., Bloise E., Nigro P., Hamed A. I., Belisario M A., Pizza C., Piacente S., J. Nat. Prod., 68, 1549-1553 (2005).

7) Kim I., Chin Y. W., Lim S. W., Kim Y. C., Kim J., Arch. Pharmacal. Res., 27, 600-603 (2004).

8) Molnar P., Deli J., Osz E., Zsila F., Simonyi M., Toth G., Helv. Chim. Acta, 87, 2159-2168 (2004).

9) Kobayashi M., Ohta Y., Phytochemistry, 22, 1257-1261 (1983).

10) Luedemann H. D., Nimz H., Makromol. Chem., 175, 2393-2407 (1974).

11) Nakajima E., Nakano H., Yamada K., Shigemori H., Hasegawa K., Phytochemistry, 61, 863-865 (2002).

12) Li G., Deng Z., Li J., Fu H., Lin W., J. Chin. Pharm. Sci., 13, 81-86 (2004).

13) Stueber D., Grant D. M., J. Am. Chem. Soc., 124, 10539-10551 (2002).

14) Moreno-Dorado F. J., Guerra F. M., Ortega M. J., Zubia E., Massanet G. M., Tetrahedron: Asymmetry, 14, 503-510 (2003).

15) Otsuka H., Kijima H., Hirata E., Shinzato T., Takushi A., Bando M., Takeda Y., Chem. Pharm. Bull., 51, 286-290 (2003).

16) Murakami T., Kishi A., Matsuda H., Hattori M., Yoshikawa M., Chem. Pharm. Bull., 49, 845-848 (2001).

17) Yu Q., Matsunami K., Otsuka H., Takeda Y., Chem. Pharm. Bull., 53, $800-807$ (2005) 